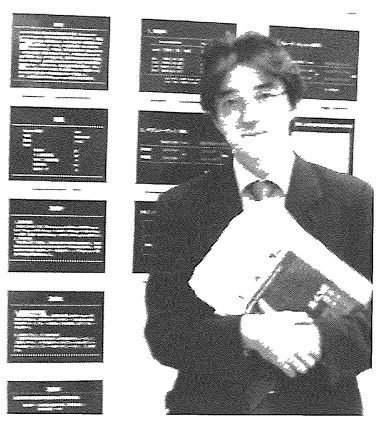

まず、このような執筆の機会をくださいました 日本癌病態治療研究会事務局ならびに関連の方々 に深く感謝いたします。

$*$

Helicobacter pylon (H pylorl) の研究を始めた のは、1994年に八王子医療センターに勤務してす ぐの頃、当時の消化器内科部長の西里先生から、 H pylorl の研究をやってみないかと持ちかけられ たのがきっかけだった。東京医科大学は東京薬科 大学と姉妹校であるため、H pylornの研究は、私 の勤めている東京医科大学八王子医療センター、 東京薬科大学微生物学教室（現在の病原微生物学 教室)、さらに八王子薬剤センタ一の三者の共同研 究という形で始まった。この共同研究の臨床・基 礎・調剤が一体化し、良い条件を与えていただき H pylornの研究を進めていくことができた。研究 テーマは、病原性をみるためのH pylornのBiotype の研究、除菌㞠法において最も注目されている抗

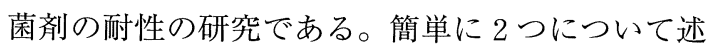
ベる。

\section{Biotype (生物型)}

細菌の分類法には、遺伝子型 (genotype)、血 清型（serotype）、生物型（biotype）などがあり、 欧米では CagA（サイトトキシン関連蛋白）が病 原性に関連するとされて多くの研究者により検討 が進められていた。われわれは、腸炎ビブリオな どにおいては細菌の病原性を血清型で検討してお
表 1 Biotype と消化器疾患

\begin{tabular}{|c|c|c|c|c|}
\hline Bıotype & $\mathrm{GU}$ & DU & $\mathrm{GU}+\mathrm{DU}$ & Gastritıs \\
\hline$I+I$ & 4 & 3 & 0 & 0 \\
\hline II + II & 20 & 20 & 8 & 5 \\
\hline III + III & 51 & 42 & 9 & 17 \\
\hline II + III & 9 & 11 & 4 & 5 \\
\hline$I+I I$ & 1 & 1 & 0 & 0 \\
\hline$I+N D$ & 0 & 0 & 1 & 0 \\
\hline
\end{tabular}

表 2 Biotype と除菌率

\begin{tabular}{|c|c|c|}
\hline 同一型 & $\begin{array}{l}\text { I + I 型 } \\
\text { II + II 型 } \\
\text { III + III 型 }\end{array}$ & $\begin{array}{ll}250 \% & (1 / 4) \\
448 \% & (13 / 29) \\
543 \% & (19 / 35)\end{array}$ \\
\hline 昆合型 & II + III 型 & $846 \% \quad(11 / 13)$ \\
\hline 全体除菌率 & & $543 \% \quad(44 / 81)$ \\
\hline
\end{tabular}

り、H pylornの病原性を Brotype で検討し、疾患特 異性および除菌率へ及ほす影響を検討した。

まずH pylornのB1otype は、API ZYM キットを 用いてKungの分類に従い、I、II、III型に分類 した。H pylor は前庭部と体部を別々に分離培養 したところ、疾患とBiotypeの関連は表 1 のよう に認められなかった。除菌療法との検討では、 Lansoprazole 30mg + Amoxıc1lln (AMPC) 1500mg の 2 週間投与による除菌療法では、前庭部と体部 でBiotypeが異なる II + III型において高い除菌率 が得られた（表 2 )。

\section{2。耐性菌}

H pylor は感杂症であり、通常われわれは感杂 
症の治療を行う場合、その細菌に対する各種抗菌 剂の薬剂感受性試験を行い、抗菌剂を選択し投与 している。H.pyloriの培養、薬剤感受性試験は煩 雑であるため、一般に感受性試験は行われていな いのが実情である。われわれは、患者から培養し た菌株をできる限り、薬剤感受性試験を行った。 薬剂感受性は、最小発育阻止濃度 (MIC) を日本 化学療法学会方に準じ寒天平板希釈法にて測定し ている。

初回（除菌前）の各種抗菌剂の耐性菌の比率（表 3) は、 $\mathrm{AMPC}(\geqq 3.13 \mu \mathrm{g} / \mathrm{ml}): 0.3 \%$ (3/802)、 Clarithromycin (CAM) $(\geqq 3.13 \mu \mathrm{g} / \mathrm{ml}): 6.3 \%$ (49/787)、Metronizazole (MNZ) $(\geqq 12.5 \mu$ $\mathrm{g} / \mathrm{ml}): 3.7 \%(28 / 773) 、$ Cefaclor $(\mathrm{CCL})(\geqq$ $3.13 \mu \mathrm{g} / \mathrm{ml}): 2.2 \%(17 / 773)$, sparfloxacin (SPFX) ( $\geqq 3.13 \mu \mathrm{g} / \mathrm{ml}): 8.8 \%(68 / 771)$ であ り、欧米に比べると MNZの耐性菌の比率が低く、 CAM、SPFXの耐性菌の比率が高かった。これら はH.pylori 以外の呼吸器疾患など感染症において、 本邦ではマクロライド系、ニューキノロン系抗菌 剂が多く使用されていることに起因する可能性が 推測されている。

また、さらに多剂耐性菌が1.4\%（9/610）の人 に認められた。 3 剂耐性が 4 例 (CAM + CCL +
SPFX : 2 例、CAM + MNZ + SPFX : 1 例、 $\mathrm{AMPC}+\mathrm{CAM}+\mathrm{MNZ}: 1$ 例)、 2 剂耐性が 5 例 $(\mathrm{CAM}+\mathrm{SPFX}: 4$ 例、 $\mathrm{CAM}+\mathrm{CCL} ： 1$ 例 $)$ であ る。これら 9 人の患者に対する問診によると、以 前より慢性気管支炎、慢性副鼻腔炎にてこれまで に多種類・多数の抗菌剤を長期にわたり服用して いる患者が多かった。

\section{除菌治療と薬剈耐性}

前項にて各種薬剂に対する薬剤耐性の頻度を検 討したが、本項では、薬剂耐性が除菌療法に及ぼ す影響、さらに除菌療法が起こす薬剤耐性につい て述べる。

現在の除菌レジメは、proton pump inhibitor $(\mathrm{PPI})+\mathrm{AMPC}+\mathrm{CAM}$ の 1 週間投与による 3 剂 療法が基本レジメであるが、この 3 剂療法にて除 菌治療を行った 257 例において、除菌療法前の AMPC 耐性は 1 株、CAM 耐性は 31 株に認められ た。薬片耐性が除菌治療に及ぼす影響を検討する 目的にて、除菌前にCAMが前庭部・体部ともに 感受性であった CAM 感受性症例と前庭部・体部 いずれか、あるいは両者がCAM 耐性であった CAM 而性症例に分けて、それぞれの除菌率を検討 した。除菌前に前庭部・体部いずれも薬剤感受性 を測定できたものが 190 例、うち感受性症例 172
表 3 各種抗菌剈に対するMIC 值別の H.pylori菌株数

\begin{tabular}{cccccc}
\hline \multicolumn{1}{c}{ MIC } & AMPC & CAM & MNZ & CCL & SPFX \\
\hline 0.0125 & $523(65.2 \%)$ & $139(17.7 \%)$ & $0(0 \%)$ & $202(26.1 \%)$ & $12(1.6 \%)$ \\
0.025 & $126(15.7 \%)$ & $186(23.6 \%)$ & $0(0 \%)$ & $147(19.0 \%)$ & $20(2.6 \%)$ \\
0.05 & $79(9.9 \%)$ & $287(36.5 \%)$ & $0(0 \%)$ & $126(16.3 \%)$ & $29(3.8 \%)$ \\
0.1 & $46(5.7 \%)$ & $90(11.4 \%)$ & $4(0.5 \%)$ & $84(10.9 \%)$ & $183(23.7 \%)$ \\
0.2 & $13(1.6 \%)$ & $25(3.2 \%)$ & $12(1.6 \%)$ & $79(10.2 \%)$ & $291(37.7 \%)$ \\
0.39 & $7(0.9 \%)$ & $7(0.9 \%)$ & $12(1.6 \%)$ & $56(7.2 \%)$ & $116(15.0 \%)$ \\
0.78 & $4(0.5 \%)$ & $3(0.4 \%)$ & $70(9.1 \%)$ & $32(4.1 \%)$ & $31(4.0 \%)$ \\
1.56 & $1(0.1 \%)$ & $1(0.1 \%)$ & $249(32.2 \%)$ & $30(3.9 \%)$ & $21(2.7 \%)$ \\
3.13 & $0(0 \%)$ & $5(0.6 \%)$ & $306(39.6 \%)$ & $6(0.8 \%)$ & $23(3.0 \%)$ \\
6.25 & $1(0.1 \%)$ & $6(0.8 \%)$ & $92(11.9 \%)$ & $5(0.6 \%)$ & $31(4.0 \%)$ \\
12.5 & $2(0.2 \%)$ & $4(0.5 \%)$ & $13(1.7 \%)$ & $4(0.5 \%)$ & $12(1.6 \%)$ \\
25 & $0(0 \%)$ & $21(2.7 \%)$ & $3(0.4 \%)$ & $2(0.3 \%)$ & $1(0.1 \%)$ \\
50 & $0(0 \%)$ & $11(1.4 \%)$ & $6(0.8 \%)$ & $0(0 \%)$ & $1(0.1 \%)$ \\
100 & $0(0 \%)$ & $2(0.3 \%)$ & $6(0.8 \%)$ & $0(0 \%)$ & $0(0 \%)$ \\
\hline
\end{tabular}

AMPC :アモキシシリン、CAM：クラリスロマイシン、MNZ:メトロニダゾール

CCL:セファクロル、SPFX:スパラフロキサシン
表 4 除菌前のCAM 感受性別の 3 剤療法 $(P P I+A M P C+C A M)$ の除菌率の検討

\begin{tabular}{lc}
\hline & 除菌率 \\
\hline CAM 感受性菌のみの患者 & $90.1 \%(155 / 172)$ \\
CAM 而性菌を有する患者 & $11.1 \%(2 / 18)$ \\
\hline CAM : クラリスロマイシン &
\end{tabular}

表 53 剤療法除菌療法前後の H.pylori菌の CAM 感受性の変化

\begin{tabular}{lrc}
\hline & \multicolumn{1}{c}{ 除菌前 } & 除菌後 \\
\hline CAM 感受性菌 & $93.2 \%(411 / 452)$ & $33.8 \%(24 / 71)$ \\
CAM 而性菌 & $6.8 \%(31 / 452)$ & $66.2 \%(47 / 71)$ \\
\hline CAM・クラリスロマイシン &
\end{tabular}


表 6 3 剂療法不成功後 CAM 耐性症例におけ る除菌前後の H.pyloriの感受性の変化

\begin{tabular}{cccc}
\hline & 除菌前 & 除菌後 & \\
\hline I & $S-S$ & $R-R$ & 6 症例 \\
II & $S-R$ & $R-R$ & 4 症例 \\
III & $R-R$ & $R-R$ & 7 症例 \\
\hline
\end{tabular}

$S:$ 感受性菌、R：耐性菌

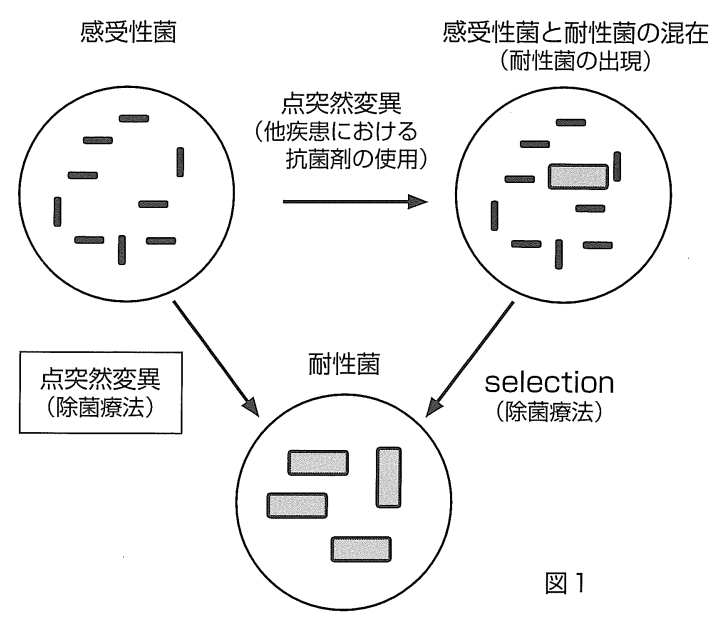

ている。

さらに 3 剂療法（PAC）除菌不成功後 CAM 而 性であった症例で、前庭部、体部のMICが除菌前 後においてすべて測定し得た17例において、除菌 前後の薬剤感受性の変化を詳細に検討した。表 6

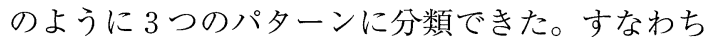
I 型として除菌前は前庭部、体部ともに感受性菌 （S-S）から除菌後両部位とも耐性菌（R-R）となる もの、II 型として除菌前は前庭部、体部のいずれ かが感受性菌で他方が耐性菌（S-R）であったもの が除菌後両部位とも耐性菌（R-R）となるもの、III 型として除菌前は前庭部、体部いずれも耐性菌（RR）が除菌後もそのまま両部位とも耐性菌（R-R） として残存するものである。

以上より、図 1 に示す模式図のように除菌後の 耐性菌増加の機構には、23SrRNAの point mutation とともにH.pylori の菌の selectionによるもの両者 が起こっている可能性があると考えている。

*

最後に、この研究を通じて他の大学・研究機関 の先生方と知り合いになれましたことが、本当に 良かったと思っております。東京薬科大学の笹津 教授をはじめとする共同研究者の方々にも深く感 謝いたしております。

今後も地道な臨床研究を続けていきたいと考え ております。 